\title{
Lipid-protein interactions in stacked and destacked thylakoid membranes and the influence of phosphorylation and illumination. Spin label ESR studies
}

\author{
Gang Li ${ }^{1}$, Peter F. Knowles ${ }^{1}$, Denis J. Murphy ${ }^{3}$ and Derek Marsh ${ }^{2}$ \\ 'Astbury Department of Biophysics, University of Leeds, Leeds (U.K.), ${ }^{2}$ Max-Planck-Institut für biophysikalische Chemie, \\ Abteilung Spektroskopie, Göttingen (F.R.G.) and ${ }^{3}$ Department of Biological Sciences, Durham University, Durham (U.K.)
}

(Received 11 December 1989)

Key words: Thylakoid membrane; Stacking/destacking; Protein phosphorylation; Photosystem; Lipid-protein interaction; Spin label; ESR

The effects of membrane destacking, protein phosphorylation, and continuous illumination have been studied in pea thylakoid membranes using ESR spectroscopy of an incorporated spin-labelled phosphatidylglycerol. This spin-labelled analogue of an endogenous thylakoid lipid has previously been shown to exhibit a selectivity of interaction with thylakoid proteins. Neither destacking, phosphorylation nor illumination was found to change the ESR spectra appreciably, suggesting that for phosphatidylglycerol at least, neither the number of protein-associated membrane lipids nor their pattern of selectivity was altered. The redistribution of the thylakoid protein complexes in the membrane, under these various conditions, therefore takes place with conservation of the properties of the lipid/protein interface.

\section{Introduction}

A characteristic morphological feature of the thylakoids in the chloroplasts of green plants is the existence of extensive membrane stacking. The appressed and non-appressed regions have very different compositions: the granal stacks are found to contain the Photosystem II and its light-harvesting complex, whereas the corresponding elements of Photosystem I, together with the ATP synthetase are located in the non-stacked stromal regions (see, for example, Refs. 1-3). The spatial segregation is reflected also in the functional differentiation of the two photosystems, PSII and PSI, respectively. The purpose of this lateral heterogeneity which accompanies stacking is thought to be the regulation of energy distribution between the two photosystems, via the phosphorylation state of the lightharvesting complex [4-6].

\footnotetext{
Abbreviations: 14-PGSL, 1-acyl-2-[14-(4,4-dimethyl- $N$-oxyl)stearoyl]$s n$-glycero-3-phosphoglycerol; EDTA, ethylenediamine tetraacetic acid; Hepes, $N$-(2-hydroxyethyl)piperazine- $N^{\prime}$-2-ethanesulphonic acid; MES, 2-( $N$-morpholino)ethanesulphonic acid; PSII, Photosystem II; PSI, Photosystem I; LHC, light-harvesting complex.
}

Correspondence: P.F. Knowles, Astbury Department of Biophysics, University of Leeds, Leeds, LS2 9JT, U.K.
By varying the ionic strength of the suspending medium, the extent of stacking can be enhanced or decreased. Slow changes in thylakoid membrane stacking are also induced in response to environmental factors such as growth temperature or light conditions. It has been found that during the stacking or destacking process there is a lateral rearrangement of protein components, accompanying the dramatic change in degree of intermembrane association in the thylakoids $[1,4,5]$. It is therefore reasonable to postulate that there may be changes in the lipid-protein interactions within the membrane during the stacking or destacking process and also on phosphorylation of the membrane.

In the present work, we have investigated the effects of membrane stacking, protein phosphorylation, and illumination conditions on the lipid-protein interactions in pea thylakoid membranes. The studies have been carried out using a spin-labelled analogue of phosphatidylglycerol, which is one of the negatively charged lipid components of the thylakoid membranes and which has previously been shown to express a selectivity of lipid-protein interaction in both the PSI and PSII photosystems [7]. The experiments shed light on the nature of the lipid/protein interface, and hence on the aggregation state of the protein complexes, in stacked and destacked thylakoids, as well as during the redistribution of the light-harvesting complex on phosphorylation. 


\section{Materials and Methods}

Spin-labelled phosphatidylglycerol, 14-PGSL, was prepared from the corresponding spin-labelled phosphatidylcholine by headgroup exchange catalyzed by phospholipase D. The preparative method, including that for the synthesis of spin-labelled phosphatidylcholine is given in Ref. 8. Ferredoxin-NADP ${ }^{+}$reductase from spinach leaves was obtained from Sigma (St. Louis, MO).

Pea seeds (Pisium sativum L, var. Kelvedon Wonder) were germinated directly in vermiculite, kept in the dark for the first 5 days at $25^{\circ} \mathrm{C}$, and then transferred to a controlled growth room $\left(20^{\circ} \mathrm{C}, 12 \mathrm{~h}\right.$, light/dark). Leaves were harvested after approximately 14 days of growth, following a period of $12 \mathrm{~h}$ dark (to reduce starch levels) and $1 \mathrm{~h}$ light (to increase chlorophyll content and degree of stacking). The leaves were homogenized in grinding medium ( $330 \mathrm{mM}$ glucose, $50 \mathrm{mM} \mathrm{Na}_{2} \mathrm{HPO}_{4}$, $50 \mathrm{mM} \mathrm{K}_{2} \mathrm{HPO}_{4}, 5 \mathrm{mM} \mathrm{MgCl}_{2}, 25 \mathrm{mM} \mathrm{NaCl}(\mathrm{pH} \mathrm{6.5)})$ with two bursts of $2 \mathrm{~s}$ in a chilled blender. The homogenate was filtered through eight layers of muslin, and the filtrate centrifuged briefly $(30 \mathrm{~s}, 2500 \times g)$ to sediment the chloroplasts. The pellets were then resuspended and vortex mixed gently for $20-60 \mathrm{~s}$ in a small volume of $5 \mathrm{mM} \mathrm{MgCl}$. The stacked thylakoids were then twice washed free of lysed chloroplast envelopes, by further centrifugation after resuspension in $330 \mathrm{mM}$ sorbitol, $2 \mathrm{mM}$ EDTA, $5 \mathrm{mM} \mathrm{MgCl}_{2}, 50 \mathrm{mM}$ Hepes (pH 7.6). The final pellets were resuspended in the same buffer and kept in the dark at $4^{\circ} \mathrm{C}$ until further use. For the phosphorylation experiments, the 1-h period of light before harvesting the leaves was omitted and the thylakoid preparation was performed under dim green light.

Lettuce (Lactuca sativa) was obtained locally. The leaves were kept in the dark for more than $8 \mathrm{~h}$ before use. Lettuce thylakoids were prepared by the same procedure as for pea thylakoids, except that the buffer used for homogenizing the leaves and for resuspension of the thylakoids contained $330 \mathrm{mM}$ sorbitol, $10 \mathrm{mM}$ EDTA, $1 \mathrm{mM} \mathrm{MgCl}_{2}, 0.5 \mathrm{mM} \mathrm{K} \mathrm{HPO}_{4}, 5 \mathrm{mM}$ $\mathrm{Na}_{4} \mathrm{P}_{2} \mathrm{O}_{7}, 1 \mathrm{mM}$ sodium ascorbate and $10 \mathrm{mM}$ Tricine (pH 8.3 (adjusted with $\mathrm{KOH}$ )). The lettuce thylakoids, prepared as above, were then washed three times with ascorbate-free buffer before spin-labelling for ESR measurements.

The chlorophyll $a / b$ ratio of both leaves and thylakoid preparations was measured by the method of Arnon [9]. Values for the thylakoid preparations were similar to those for the intact leaves (approx. 2.4). Any preparations with appreciably lower values were discarded. The intactness and purity of the thylakoid preparations were also checked by thin-section electron microscopy, according to the methods described below. The electron micrographs showed that the preparations were essentially free of contamination by other membranes and organelles.

Oxygen evolution of the lettuce thylakoid preparations $(50 \mu \mathrm{g}$ chlorophyll $/ \mathrm{ml}$ ) was measured in $300 \mathrm{mM}$ sorbitol, $50 \mathrm{mM} \mathrm{KCl}, 5 \mathrm{mM} \mathrm{MgCl}, 20 \mathrm{mM}$ Tricine (pH 7.6 (adjusted with $\mathrm{KOH}$ )), and $5 \mu$ mol ferredoxin$\mathrm{NADP}^{+}$and 0.1 unit reductase for each $0.33 \mathrm{mg}$ chlorophyll, at $20^{\circ} \mathrm{C}$. The rate determined using a Hansatech oxygen electrode was $24.8 \mu \mathrm{mol} \mathrm{O}{ }_{2}$ per mg chlorophyll per $h$.

For spin-labelling, thylakoid membranes comprising approximately $2 \mathrm{mg}$ of polar lipids were suspended in 2-3 ml of $20 \mathrm{mM} \mathrm{Mes,} 50 \mathrm{mM} \mathrm{KCl}, 5 \mathrm{mM} \mathrm{MgCl}_{2}$ (pH 6.5) and $20 \mu 1$ of $1 \mathrm{mg} / \mathrm{ml}$ 14-PGSL spin-label solution in ethanol was added slowly. The sample was then vortex mixed briefly and incubated for 15-20 min in the dark at room temperature. The spin-labelled sample was centrifuged (45 min, $90000 \times \mathrm{g}, 4^{\circ} \mathrm{C}$ ) and washed in $13 \mathrm{ml}$ of the same buffer, using a Beckmann SW-40 swing-out rotor. Different states of membrane stacking and phosphorylation were achieved by incubating with the appropriate buffers (see Results, below) for a period of $30 \mathrm{~min}$, either with or without illumination $(0.2$ mEinstein $\cdot \mathrm{m}^{-2} \cdot \mathrm{s}^{-1}$ ) as required. After a final centrifugation the pellet was transferred with about $10 \mu 1$ of the same buffer to a $100 \mu 1$ capillary ( $1 \mathrm{~mm}$ i.d.) sealed at one end. The sample was then packed using a benchtop centrifuge prior to sealing and ESR measurement.

ESR spectra were recorded on a Bruker ER200 9 $\mathrm{GHz}$ spectrometer equipped with a nitrogen gas flow system for temperature control to within $\pm 0.5^{\circ} \mathrm{C}$. The spectrometer was interfaced to an Acorn 1770DFS microcomputer with Microlink interface (Biodata, Manchester, U.K.) via an IEEE-488 bus. The sample capillaries were accommodated within a standard $4 \mathrm{~mm}$ quartz ESR tube which contained light silicone oil for thermal stability. For the in situ illumination experiments, the thylakoid membranes were contained at a concentration of $0.33 \mathrm{mg}$ chlorophyll in $0.4 \mathrm{ml}$ in a flat quartz ESR cell (width $1 \mathrm{~cm}$ ). Illumination of the sample in the microwave cavity was effected through the irradiation port with maximum light intensity (approx. $0.2 \mathrm{mEinstein} \cdot \mathrm{m}^{-2} \cdot \mathrm{s}^{-1}$ ) from a slide projector. Spectral subtraction was performed essentially as described in Ref. 10.

Thin sections were prepared for electron microscopy, as described in Ref. 11, except that the resin used for embedding was obtained from TAAB Laboratory Equipment Services. The thin sections were examined with a Phillips EM-200 electron microscope operating at a voltage of $60 \mathrm{kV}$.

\section{Results and Discussion}

Stacked and unstacked thylakoid preparations were obtained by suspending the samples in buffers of differ- 

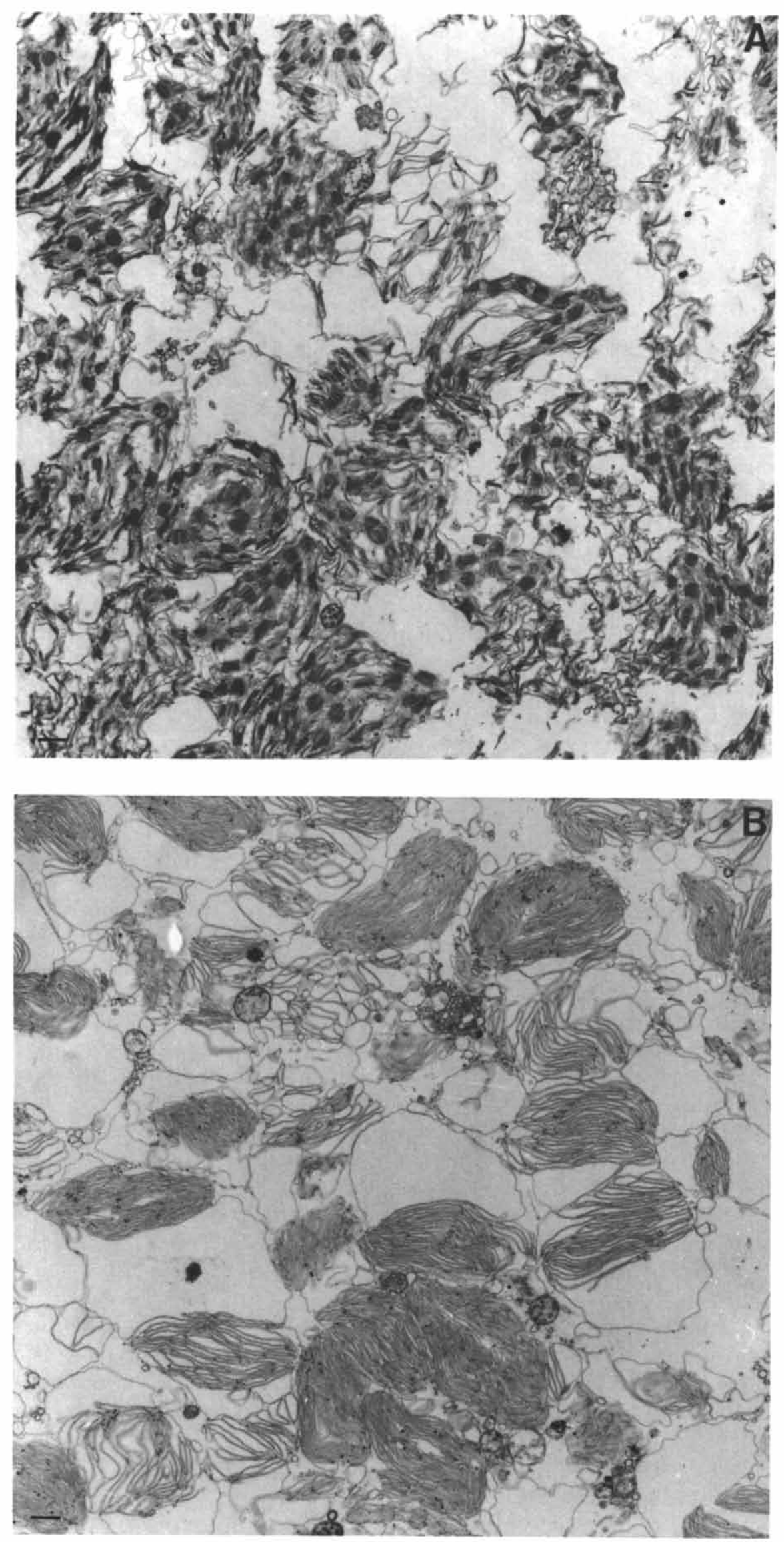

Fig. 1. Thin-section electron micrographs of: (A, C) normal stacked pea thylakoids in $50 \mathrm{mM} \mathrm{KCl}, 5 \mathrm{mM} \mathrm{MgCl} 2,20 \mathrm{mM}$ Mes (pH 6.5 (adjusted 

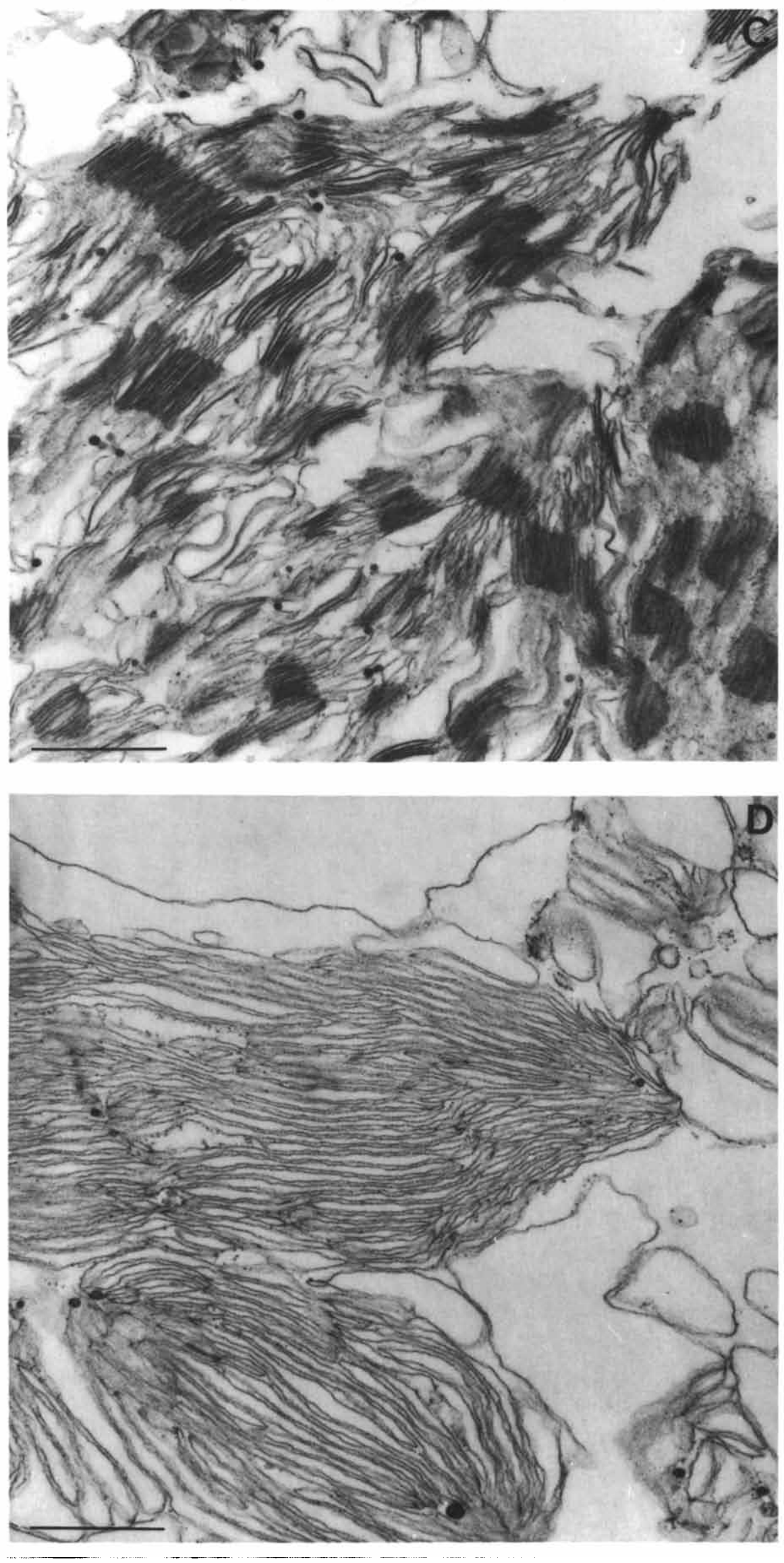

with $\mathrm{KOH}$ )) and (B, D) destacked pea thylakoids in $60 \mathrm{mM}$ sorbitol, $0.2 \mathrm{mM} \mathrm{MgCl} 2,20 \mathrm{mM}$ Mes (pH 6.5 (adjusted with Tris)). Bar $=1 \mu \mathrm{m}$. 
ent ionic strength (cf. Refs. 12, 13). As shown in Figs. $1 \mathrm{~A}, \mathrm{C}$ the thylakoids suspended in buffer of the higher ionic strength have the normal granal morphology, whereas those suspended in the buffer of lower ionic strength are completely destacked (Fig. 1B, D). The ESR spectra of the 14-PGSL spin label in stacked and destacked thylakoid membrane samples are given in Figs. $2 \mathrm{a}$ and $\mathrm{b}$, respectively. Both preparations display the two-component spectra characteristic of lipid-protein interactions in thylakoid membrane systems [7]. However, no significant differences are observed between the stacked and destacked membranes, in the spectral lineshapes either of the broader motionally restricted lipid component that corresponds to the lipid population interacting with the integral membrane proteins, or of the narrower fluid lipid component that corresponds to the bulk lipid regions of the membrane. In addition, the relative proportions of the two components are also very similar in the stacked and destacked membranes. ESR spectra of the 5-position, 5-PGSL, label are given in Fig. 3. These spectra are characteristic of the more limited motion of the chain segments closer to the polar headgroup of the phospholipid (even at the somewhat higher temperature). For this region of the

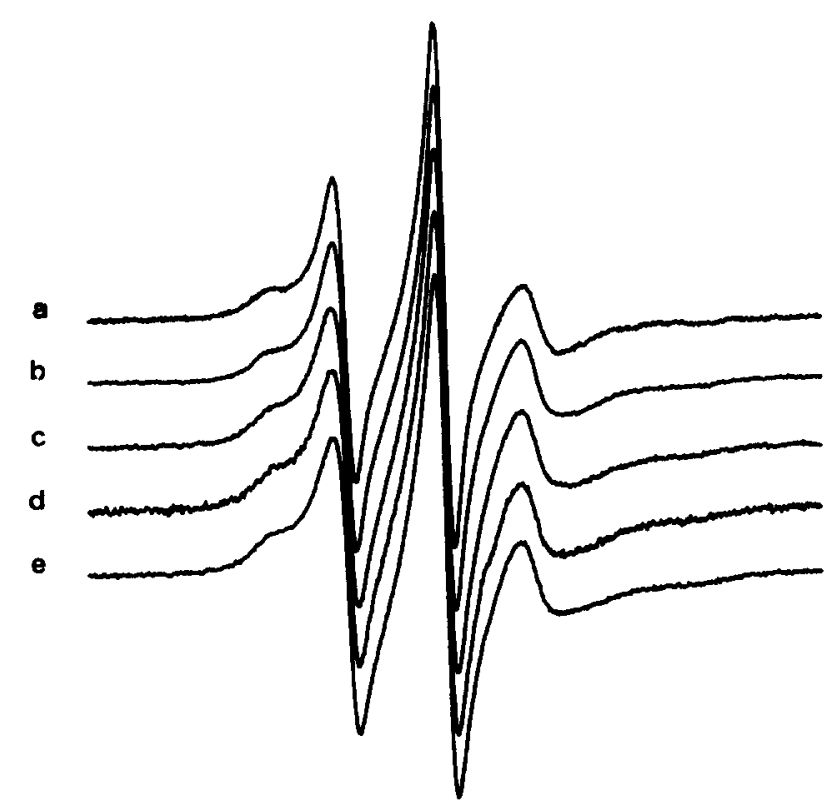

Fig. 2. ESR spectra of the 14-PGSL spin label in non-phosphorylated and phosphorylated pea thylakoid membranes, suspended in buffers of different stacking potential. (a) In $50 \mathrm{mM} \mathrm{KCl}, 5 \mathrm{mM} \mathrm{MgCl} 2,20$ $\mathrm{mM}$ Mes (pH 6.5 (adjusted with $\mathrm{KOH}$ )). (b) In $60 \mathrm{mM}$ sorbitol, 0.2 $\mathrm{mM} \mathrm{MgCl} 2,20 \mathrm{mM}$ Mes (pH 6.5 (adjusted with Tris)). (c) In $300 \mathrm{mM}$ sorbitol, $25 \mathrm{mM} \mathrm{KCl}, 3.3 \mathrm{mM} \mathrm{MgCl}$, $10 \mathrm{mM} \mathrm{NaF}, 33 \mathrm{mM}$ Tricine (pH 7.5 (adjusted with $\mathrm{NaOH}$ )), with avoidance of exposure to light. (d) In $300 \mathrm{mM}$ sorbitol, $25 \mathrm{mM} \mathrm{KCl}, 3.3 \mathrm{mM} \mathrm{MgCl}, 10 \mathrm{mM} \mathrm{NaF}, 33$ $\mathrm{mM}$ Tricine, $0.2 \mathrm{mM}$ ATP (pH 7.5 (adjusted with $\mathrm{NaOH}$ )), with incubation under strong light $\left(0.2 \mathrm{mEinstein} \cdot \mathrm{m}^{-2} \cdot \mathrm{s}^{-1}\right)$. (e) In 330 $\mathrm{mM}$ sorbitol, $0.2 \mathrm{mM} \mathrm{MgCl}, 10 \mathrm{mM} \mathrm{NaF}, 33 \mathrm{mM}$ Tricine, $0.2 \mathrm{mM}$ ATP ( $\mathrm{pH} 7.5$ (adjusted with Tris)), with incubation under strong light $\left(0.2 \mathrm{mEinstein} \cdot \mathrm{m}^{-2} \cdot \mathrm{s}^{-1}\right)$. Scan range $=100$ gauss; $T=24^{\circ} \mathrm{C}$.

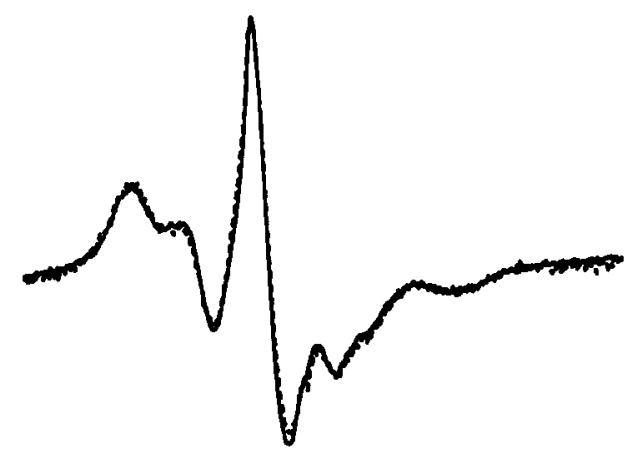

Fig. 3. ESR spectra of the 5-PGSL spin label in stacked and destacked pea thylakoid membranes. Full line: in $50 \mathrm{mM} \mathrm{KCl}, 5 \mathrm{mM} \mathrm{MgCl}{ }_{2}, 20$ $\mathrm{mM}$ Mes (pH 6.5 (adjusted with $\mathrm{KoH}$ )). Dashed line: in $60 \mathrm{mM}$ sorbitol, $0.2 \mathrm{mM} \mathrm{MgCl}$, $20 \mathrm{mM}$ Mes (pH 6.5 (adjusted with Tris)). Scan range $=100$ gauss; $T=30^{\circ} \mathrm{C}$.

membrane, it is also seen that there is very little difference in the lipid chain motion between the stacked and destacked thylakoid membranes.

The effects of protein phosphorylation have been investigated by illumination in the presence of ATP [14] in buffers of different stacking potential, prior to recording the spin label ESR spectra. The ESR spectra of the 14-PGSL label in a stacked non-phosphorylated control sample, in a phosphorylated sample (which is only approx. $20 \%$ destacked $[15,16])$, and in a phosphorylated and destacked sample, are given in Figs. 2c, d, and $e$, respectively. Here again, destacking and phosphorylation, either separately or in combination, have little effect on the lipid-protein interactions in the thylakoid membranes.

The effects of continuous illumination on the lipidprotein interactions in thylakoid membranes have also been studied. The ESR spectra of the 14-PGSL spin label in thylakoid membranes under strong illumination and in the dark are compared in Fig. 4. Experiments were carried out both in the absence and in the presence of ferredoxin-NADP ${ }^{+}$reductase. Under the latter conditions, the preparations actively evolve oxygen on illumination (cf. Materials and Methods). Experiments were carried out not only at $\mathrm{pH} 6.5$, but also at $\mathrm{pH} 7.6$ which corresponds to the $\mathrm{pH}$ optimum of the ferredoxin-NADP ${ }^{+}$reductase. Although differences are seen in the extent of the light-induced ESR signal from the photocentres (signal I), before it is removed by subtraction for the sample in the absence of ferredoxin-NADP ${ }^{+}$ reductase, the lipid spin-label spectra are very similar both under strong illumination and in the dark (Fig. $4 c)$. In the presence of ferredoxin-NADP ${ }^{+}$reductase there is also no change in the lipid spin label spectra when they are recorded under illumination and the preparations are actively evolving oxygen (Figs. 4a, b).

In summary, the results indicate relatively little change in the lipid-protein interactions in thylakoid membranes on destacking, or on phosphorylation, in 


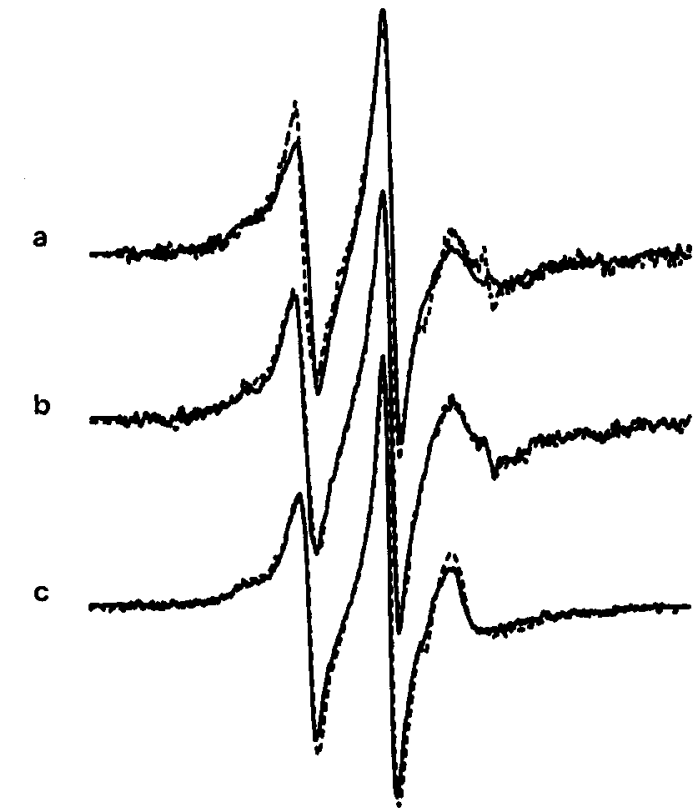

Fig. 4. ESR spectra of the 14-PGSL spin label in lettuce and pea thylakoid membranes under different illumination conditions. Full line: under strong light. Dashed line: in the dark. (a) Lettuce thylakoids in $300 \mathrm{mM}$ sorbitol, $50 \mathrm{mM} \mathrm{KCl}, 5 \mathrm{mM} \mathrm{MgCl}{ }_{2}, 20 \mathrm{mM}$ Tricine $(\mathrm{pH}$ 7.6 (adjusted with $\mathrm{KOH}$ )), and $5 \mu \mathrm{mol}$ ferredoxin-NADP ${ }^{+}$and 0.1 unit reductase for each $0.33 \mathrm{mg}$ chlorophyll. (b) Lettuce thylakoids in $300 \mathrm{mM}$ sorbitol, $50 \mathrm{mM} \mathrm{KCl}, 5 \mathrm{mM} \mathrm{MgCl}, 20 \mathrm{mM}$ Mes (pH 6.5 (adjusted with $\mathrm{KOH}$ )), and $5 \mu \mathrm{mol}$ ferredoxin-NADP ${ }^{+}$and 0.1 unit reductase for each $0.33 \mathrm{mg}$ chlorophyll. (c) Pea thylakoids in $300 \mathrm{mM}$ sorbitol, $50 \mathrm{mM} \mathrm{KCl}, 5 \mathrm{mM} \mathrm{MgCl} 2,20 \mathrm{mM}$ Mes (pH 6.5 (adjusted with $\mathrm{KOH}$ )). The light-induced ESR signal in (c) has been removed by subtracting the spectra from unlabelled membranes. Scan range $=100$ gauss; $T=20^{\circ} \mathrm{C}$.

spite of the rearrangement of the protein components which occur in the membrane under these conditions. Neither the number of lipid sites at the protein interface, nor the selectivity previously found for phosphatidylglycerol [7], appears to change. The implication, therefore, is that the redistribution of protein components occurs with preservation of the essential characteristics of the lipid/protein interface. The lipid-protein complexes of the photosystems in the stacked membranes appear to remain intact on their random dispersal in the unstacked membranes, and no interaction seems to occur between the PSI and PSII complexes which would either displace lipids at the protein interface or disturb the intramembranous lipid-protein interactions appreciably.

The situation with regard to phosphorylation is particularly interesting, since a subpopulation of the lightharvesting complex is thought to shift its association from the PSII complex to the PSI complex on phosphorylation $[4,6]$. Reasoning from the spin-label data, these different protein-protein associations most probably occur without change in the number of protein-associated lipids. Either the associations of the LHC occur via the lipid/protein interface in both states, or the association sites exclude an equivalent number of lipids without changing the overall degree of selectivity for phosphatidylglycerol. Phosphorylation itself might be expected to change the selectivity for phosphatidylglycerol by changing the net charge on the protein. Such effects have been seen, for instance, following covalent modification of the lysine groups on cytochrome oxidase [17]. The lack of any such effect in the present work suggest that the phosphorylation sites are too remote from the polar/apolar interface of the membrane to influence the lipid selectivity. Such an interpretation would be consistent with the finding that the primary site of phosphorylation is located in the $\mathrm{N}$-terminus of the LHC complex, which is cleavable by trypsin and is located at the stromal face of the thylakoid $[6,18]$.

Strong illumination was found not to change the lipid-protein interactions, in spite of the fact that this induces an extremely close appression of the thylakoid membranes and a consequent reduction in the mobility of certain thylakoid lumen-oriented proteins, such as the peripheral components of the PSII complex [19]. It has recently been shown that the illumination of darkadapted thylakoid membranes does not affect the rate of MGDG breakdown by Rhizopus arrhizus lipase, except under photophosphorylating conditions [20]. This was interpreted to indicate that MGDG packing was not changed during a dark-to-light transition, even under conditions of high electron transport, unless the illuminated thylakoids were simultaneously driving net ATP synthesis. These conclusions are consistent with the data from the present study where lipid-protein interactions were assayed more directly using ESR spectroscopy. Previous studies (apart from Ref. 20) have concentrated on the physical state of the thylakoid membranes under resting, i.e., non-illuminated, conditions. It appear that some aspects of thylakoid organisation, e.g., lipid-protein interactions, may be independent of light-indcuced membrane protein phosphorylation or electron transport but are affected by other physiological processes, such as ATP synthesis. Clearly, the dynamic nature of lipid packing and lipid-protein interactions in physiologically active thylakoid membranes, and the implications of this for long-range diffusional processes (e.g., plastoquinone or LHC movement) requires further study.

\section{Acknowledgements}

We thank Dr. J.F. Allen for help and advice with the oxygen electrode epxeriments which were performed in his laboratory, and Denise Ashworth for carrying out the electron microscopy. G.L. was a research student jointly sponsored by the British Council and the Ministry of Education of China. 


\section{References}

1 Barber, J. (1985) in Photosynthetic Mechanisms and the Environment (Barber, J. and Baker, N.R., eds.), pp. 91-134, Elsevier, Amsterdam.

2 Anderson, J.M. and Andersson, B. (1982) Trends Biochem. Sci. 7, 288-292.

3 Murphy, D.J. (1986) Biochim. Biophys. Acta 864, 33-94.

4 Staehelin, L.A. and Arntzen, C.J. (1983) J. Cell Biol. 97, 1327-1337.

5 Miller, K.R. and Lyon, M.K. (1985) Trends Biochem. Sci. 10, 219-222.

6 Bennett, J. (1983) Biochem. J. 212, 1-13.

7 Li, G., Knowles, P.F., Murphy, D.J., Nishida, I. and Marsh, D. (1989) Biochemistry 28, 7446-7452.

8 Marsh, D. and Watts, A. (1982) in Lipid-Protein Interactions (Jost, P.C. and Griffith, O.H., eds.), Vol. 2, pp. 53-126, Wiley-Interscience, New York.

9 Arnon, D.I. (1949) Plant Physiol. 24, 1-15.
10 Marsh, D. (1982) Techn. Life Sci.: Biochem. B4, B426/1$B / 426 / 44$.

11 Telfer, A., Nicholson, J. and Barber, J. (1976) FEBS Lett. 65, 77-83.

12 Izawa, S. and Good, N.E. (1966) Plant Physiol. 41, 544-552.

13 Barber, J. and Chow, W.S. (1979) FEBS Lett. 105, 5-10.

14 Bhalla, P. and Bennett, J. (1987) Arch. Biochem. Biophys. 252, 97-104.

15 Haworth, P. and Melis, A. (1983) FEBS Lett. 160, 277-280.

16 Telfer, A., Hodges, M., Millner, P.A. and Barber, J. (1984) Biochim. Biophys. Acta 766, 554-562.

17 Powell, G.L., Knowles, P.F. and Marsh, D. (1987) Biochemistry 26, 8138-8145.

18 Mullet, J.E. (1983) J. Biol. Chem. 258, 9941-9948.

19 Haehnel, W. (1984) Annu. Rev. Plant Physiol. 35, 659-693.

20 Rawyler, A. and Siegenthaler, P.A. (1989) Biochim. Biophys. Acta 975, 283-292. 